\title{
Genetic diversity of Phytophthora capsici (Pythiaceae) isolates in Anhui Province of China based on ISSR-PCR markers
}

\author{
P. Li, S. Cao, Y.L. Dai, X.L. Li, D.F. Xu, M. Guo, Y.M. Pan and Z.M. Gao \\ School of Plant Protection, Anhui Agricultural University, Hefei, China \\ Corresponding author: Z.M. Gao \\ E-mail: gaozhimou@126.com
}

Genet. Mol. Res. 11 (4): 4285-4296 (2012)

Received June 4, 2012

Accepted October 18, 2012

Published December 17, 2012

DOI http://dx.doi.org/10.4238/2012.December.17.4

\begin{abstract}
Phytophthora capsici is a plant pathogenic oomycete that damages numerous crops worldwide. Consequently, interest in research on the genetic structure of this species has grown in recent decades. However, there is little information about $P$. capsici in eastern China. We investigated the genetic diversity of $P$. capsici isolates from three large regions of Anhui Province in eastern China based on ISSRPCR technology. Thirteen random primers were screened and used to amplify DNA from 51 samples. We obtained 158 reproducible ISSR fragments, of which $90 \%$ were polymorphic, revealing a high degree of polymorphism among the isolates. Genetic similarity coefficients among all the isolates ranged from 0.56 to 0.94 , with a mean of 0.84 based on the ISSR data, indicating a high level of genetic variation in these $P$. capsici isolates. Cluster analysis using UPGMA indicated that the Anhui isolates were divided into seven groups according to the DNA fingerprints, although there was no correlation between the ISSR group and geographic origin. Isolates from the same location showed no clustering based on the year of sampling. AMOVA partitioned variability among $(13.6 \%)$ and within populations $(86.4 \%)$. The gene flow among populations ranged from 2.804 to 4.937 , with a mean of 3.545 , indicating highly frequent gene exchange. Genetic distances
\end{abstract}


and genetic differentiation were negatively correlated with geographic distances. These results lead us to suggest that this pathogen has considerable evolutionary potential, which will enable it to adapt to and overcome management strategies over time.

Key words: Phytophthora capsici; Genetic diversity; ISSR-PCR; Anhui

\section{INTRODUCTION}

Phytophthora capsici is an important soilborne oomycete pathogen of pepper (Capsicum annuum L.), which was first identified by Leonian in New Mexico with large host ranges including not only pepper but also tomato, cucumber, cucurbit, and other Solanaceae plants (Leonian, 1922; Hausbeck and Lamour, 2004). Generally, the pathogen penetrates the plant through the root and the stem and then causes necrosis of infected areas. Meanwhile, the plant withers, resulting in obstruction in the vascular system. The infected tissues dry up, shrink and turn black. It can infect all parts of the plant at any growth stage, causing damping-off, seedling blight, foliar blight, and fruit rot (Latin and Rane, 1999). Recently, the incidence of Phytophthora foliar and fruit rot has increased worldwide (Hwang and Kim, 1995; Ristaino and Johnston, 1999). It has also been reported that the disease had occurred in mainland China and become one of the serious threats to farmers (Ho and Lu, 1997).

P. capsici belongs to the phytopathogenic oomycetes that produce both zoospores and oospores for colonizing plant tissues and overwintering, and can be dispersed by surface water, irrigation water and air currents. To date, management of $P$. capsici mainly relies on rotation, sanitation and the use of fungicides, but there is no effective method to provide enough protection against this disease during its epidemic period (Babadoost and Islam, 2001). As known, the genetic structure of pathogen populations reflects its evolutionary history and its potential to evolve. Population genetic studies of pathogens are helpful in the better management of disease in agricultural ecosystems and may also serve as a guide in pepper cultivation (McDonald, 1997). For instance, by knowing the genetic variation maintained within a species, indicating the speed at which a pathogen evolves, measures such as the use of resistant cultivars or fungicides could be adopted. Therefore, knowledge of the genetic variation of $P$. capsici isolates is essential for developing effective measures to control the diseases caused by the pathogenic oomycete in crop fields.

DNA markers have now become a popular means for the identification and authentication of plant, animal and microbial species. At present, this technology has been widely used in the identification of germplasm resources and determination of genetic diversity in populations (Zhang et al., 2007). During the last decade, a number of molecular markers have been widely used to study the genetic diversity of different Phytophthora spp (Linde et al., 1999; Ochwo et al., 2002; Yang et al., 2008). Using molecular methods to investigate the genetic structure of $P$. capsici still drew a blank until the late 1980s and early 1990s (Förster et al., 1989; Oudemans and Coffey, 1991; Mchau and Coffey, 1995). Recently, molecular genetic markers, such as random amplified polymorphic DNA (RAPD), simple sequence repeat (SSR) and amplified fragment length polymorphism (AFLP), have been broadly used to learn the genetic structure of P. capsici (Lamour and Hausbeck, 2001; Silvar et al., 2006; Wang et al., 2009). Among the molecular markers, inter-simple sequence repeat (ISSR) is the easily usable and reliable one for 
investigating genetic diversity in plants, animals and fungi, and some studies have also shown that ISSR could provide high genomic polymorphism compared to restriction fragment length polymorphism, SSR and RAPD (Blair et al., 1999; Gilbert et al., 1999; Wang et al., 2009). However, little is known about the genetic structure of $P$. capsici in Anhui Province in eastern China.

In this study, ISSR-polymerase chain reaction (PCR) was used to investigate the genetic structure of $P$. capsici isolates from different geographical origins of Anhui Province. The primary aim of this study was to obtain more information on the population structure of $P$. capsici in Anhui and to explore the genetic diversity in their populations. Knowledge of the genetic diversity of $P$. capsici in Anhui will establish whether populations of $P$. capsici are genetically differentiated between fields and regions in Anhui, if specific genotypes predominate, and what the potential is for developing recombinant populations. This information can be used to improve current control strategies and to design future studies on specific questions with regard to the population structure of the pathogen within fields and across seasons in Anhui.

\section{MATERIAL AND METHODS}

\section{Isolate collection and mycelium culture}

A total of 51 isolates of $P$. capsici were used to study its genetic diversity by ISSRPCR. All of them were isolated from symptomatic diseased pepper plants collected from eight locations in Anhui Province from 2006 to 2010. Based on the localities, the samples belonged to three large populations: population between south of the Huai River and north of the Yangtze River (Pop 1) with 22 isolates, population in south of the Yangtze River (Pop 2) with 13 isolates, and population north of the Huai River (Pop 3) with 16 isolates (Figure 1, Table 1).

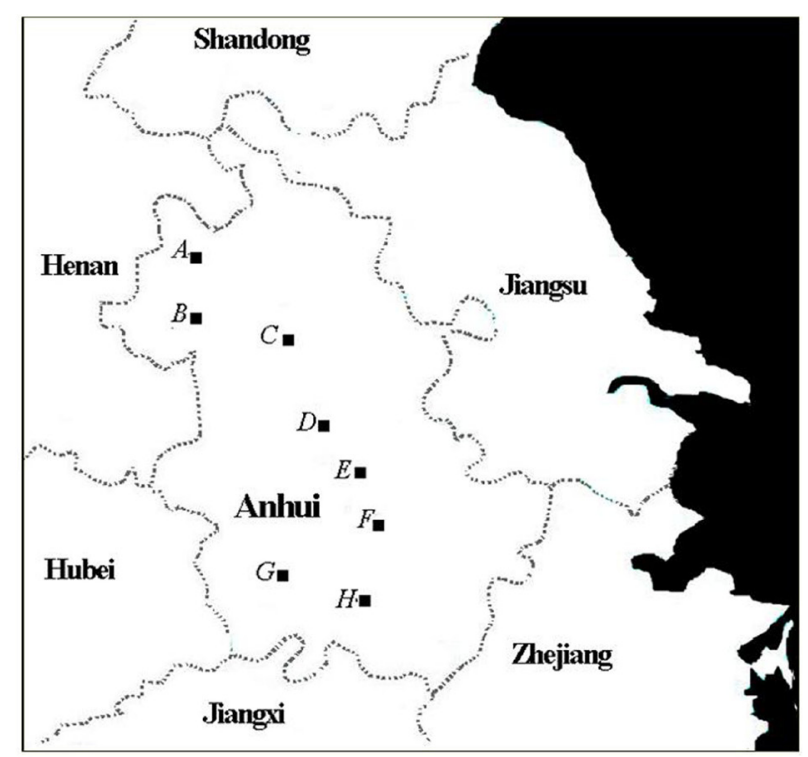

Figure 1. Map of locations sampled for Phytophthora capsici in Anhui, China, for analysis of genetic diversity: (A) Bozhou; (B) Fuyang; (C) Huainan; (D) Hefei; (E) Chaohu; (F) Tongling; (G) Anqing; (H) Chizhou. 
Table 1. Number and localities of Phytophthora capsici isolates used in this study.

\begin{tabular}{|c|c|c|c|c|}
\hline Isolate No. & Sampling site & Year of collection & No. of bands recorded & Genotype \\
\hline \multicolumn{5}{|c|}{$\begin{array}{l}\text { Between south of the Huai River and } \\
\text { north of the Yangtze River (Pop 1) }\end{array}$} \\
\hline HN1 & Huainan & 2006 & 71 & A \\
\hline HN2 & Huainan & 2006 & 70 & $\mathrm{~A}$ \\
\hline HN3 & Huainan & 2006 & 80 & $\mathrm{~A}$ \\
\hline HN4 & Huainan & 2006 & 79 & A \\
\hline HN5 & Huainan & 2006 & 80 & A \\
\hline HN6 & Huainan & 2006 & 83 & A \\
\hline HN7 & Huainan & 2006 & 76 & A \\
\hline HN8 & Huainan & 2006 & 85 & A \\
\hline HF2 & Hefei & 2007 & 54 & $\mathrm{E}$ \\
\hline HF3 & Hefei & 2007 & 56 & $\mathrm{E}$ \\
\hline HF4 & Hefei & 2007 & 51 & $\mathrm{E}$ \\
\hline HF5 & Hefei & 2007 & 64 & A \\
\hline HF6 & Hefei & 2007 & 69 & $\mathrm{~A}$ \\
\hline HF7 & Hefei & 2008 & 63 & $\mathrm{C}$ \\
\hline $\mathrm{CH} 1$ & Chaohu & 2009 & 72 & $\mathrm{~B}$ \\
\hline $\mathrm{CH} 2$ & Chaohu & 2009 & 81 & $\mathrm{~A}$ \\
\hline $\mathrm{CH} 3$ & Chaohu & 2009 & 74 & A \\
\hline AQ1 & Anqing & 2008 & 74 & $\mathrm{~A}$ \\
\hline $\mathrm{AQ} 2$ & Anqing & 2008 & 78 & A \\
\hline AQ3 & Anqing & 2008 & 66 & $\mathrm{~F}$ \\
\hline AQ4 & Anqing & 2008 & 65 & A \\
\hline AQ5 & Anqing & 2008 & 70 & A \\
\hline \multicolumn{5}{|c|}{ South of the Yangtze River (Pop 2) } \\
\hline $\mathrm{CZ1}$ & Chizhou & 2009 & 63 & $\mathrm{C}$ \\
\hline $\mathrm{CZ2}$ & Chizhou & 2009 & 69 & $\mathrm{C}$ \\
\hline TL1 & Tongling & 2010 & 76 & A \\
\hline TL2 & Tongling & 2010 & 82 & $\mathrm{C}$ \\
\hline TL3 & Tongling & 2010 & 87 & G \\
\hline TL4 & Tongling & 2010 & 84 & $\mathrm{D}$ \\
\hline TL5 & Tongling & 2010 & 81 & $\mathrm{D}$ \\
\hline TL6 & Tongling & 2010 & 78 & $\mathrm{D}$ \\
\hline TL7 & Tongling & 2010 & 93 & $\mathrm{D}$ \\
\hline TL8 & Tongling & 2010 & 65 & $\mathrm{D}$ \\
\hline TL9 & Tongling & 2010 & 67 & $\mathrm{D}$ \\
\hline TL10 & Tongling & 2010 & 73 & $\mathrm{D}$ \\
\hline TL11 & Tongling & 2010 & 63 & $\mathrm{D}$ \\
\hline \multicolumn{5}{|c|}{ North of the Huai River (Pop 3) } \\
\hline FY1 & Fuyang & 2009 & 80 & $\mathrm{~A}$ \\
\hline FY2 & Fuyang & 2009 & 80 & A \\
\hline FY3 & Fuyang & 2009 & 78 & $\mathrm{C}$ \\
\hline $\mathrm{BZ1}$ & Bozhou & 2009 & 65 & $\mathrm{C}$ \\
\hline BZ2 & Bozhou & 2010 & 72 & $\mathrm{D}$ \\
\hline $\mathrm{BZ3}$ & Bozhou & 2010 & 73 & B \\
\hline BZ4 & Bozhou & 2010 & 76 & D \\
\hline BZ5 & Bozhou & 2010 & 77 & D \\
\hline BZ6 & Bozhou & 2010 & 71 & $\mathrm{D}$ \\
\hline BZ7 & Bozhou & 2010 & 70 & $\mathrm{D}$ \\
\hline BZ8 & Bozhou & 2010 & 72 & $\mathrm{D}$ \\
\hline BZ9 & Bozhou & 2010 & 79 & D \\
\hline BZ10 & Bozhou & 2010 & 66 & $\mathrm{D}$ \\
\hline BZ11 & Bozhou & 2010 & 66 & D \\
\hline BZ12 & Bozhou & 2010 & 69 & D \\
\hline BZ13 & Bozhou & 2010 & 62 & $\mathrm{D}$ \\
\hline
\end{tabular}

All of the isolates tested were first cultivated on carrot agar for 3 days, and then grown in Plich's liquid medium $\left(0.5 \mathrm{~g} \mathrm{KH}_{2} \mathrm{PO}_{4}, 0.25 \mathrm{~g} \mathrm{MgSO}_{4} \cdot 7 \mathrm{H}_{2} \mathrm{O}, 1 \mathrm{~g}\right.$ asparagine, $1 \mathrm{mg}$ thiamine, $0.5 \mathrm{~g}$ yeast extract, $25 \mathrm{~g}$ glucose, and $1000 \mathrm{~mL}$ distilled water) as mycelial plugs $(6 \times 6 \mathrm{~mm})$, incubated on an orbital shaker $(100 \mathrm{rpm})$ for about 7 days. All mycelia were harvested and stored at $-20^{\circ} \mathrm{C}$ for DNA preparation. 


\section{DNA extraction}

Total genomic DNA of each isolate was extracted according to the methods as described by Wang and Zheng (2003), with a few modifications: the air-dried pellet was resuspended in $100 \mu \mathrm{L}$ Tris-EDTA (TE) buffer (10 mM Tris-HCl, $1 \mathrm{mM}$ EDTA, pH 7.4) and $2 \mu \mathrm{L}$ RNase $(10 \mathrm{mg} / \mathrm{mL})$ was added and the mixture incubated at $37^{\circ} \mathrm{C}$ for $1 \mathrm{~h}$. The integrity of DNA samples was checked on a $0.8 \%$ agarose gel stained with ethidium bromide. All DNA samples were checked for quantity using a spectrophotometer at $260 \mathrm{~nm}$, and then diluted to $50 \mathrm{ng} / \mu \mathrm{L}$.

\section{ISSR-PCR amplification}

A total of 40 primers synthesized by Sangon Biotechnology Ltd. Co. (Shanghai, China) were initially screened on 10 isolates. Thirteen primers (Table 2) that produced clear and reproducible bands were selected for further analysis. The amplifications were performed in a $25-\mu \mathrm{L}$ reaction mixture containing $2.5 \mu \mathrm{L} \mathrm{10X} \mathrm{PCR} \mathrm{buffer,} 200 \mu \mathrm{M}$ dNTPs, $0.2 \mu \mathrm{M}$ primer, $0.5 \mu \mathrm{L}$ template DNA, and $1.25 \mathrm{U}$ Taq DNA polymerase (Takara). Thermal cycling was programmed as follows: initial denaturation for $5 \mathrm{~min}$ at $94^{\circ} \mathrm{C}, 35$ cycles of denaturation at $94^{\circ} \mathrm{C}$ for $1 \mathrm{~min}$, annealing at a specific temperature for $1 \mathrm{~min}$, extension at $72^{\circ} \mathrm{C}$ for $2 \mathrm{~min}$, followed by a final extension at $72^{\circ} \mathrm{C}$ for $10 \mathrm{~min}$. The annealing temperatures are given in Table 2. PCR products were separated on $1.8 \%$ agarose gels containing ethidium bromide in $10 \mathrm{X}$ Tris-borate-EDTA buffer at $5 \mathrm{~V} / \mathrm{cm}$ for $3 \mathrm{~h}$ and visualized under a UV transilluminator. All amplifications were repeated 3 times to ensure their reproducibility.

\section{Data analysis}

ISSR-amplified fragments were scored either as present (1) or absent (0) on the basis of the molecular weight (bp) for each isolate, and the data were then converted to a binary matrix. P. capsici population genetic parameters were analyzed using POPGENE version 1.3.1 to calculate the number of polymorphic bands, the percentage of polymorphic bands (PPB), observed number of alleles $\left(N_{\mathrm{A}}\right)$, effective number of alleles $\left(N_{\mathrm{E}}\right)$, Nei's gene diversity $(h)$, Shannon's information index $\left(I_{s}\right)$, total genetic diversity $\left(H_{t}\right)$, genetic diversity within groups $\left(H_{s}\right)$ and the relative magnitude of genetic differentiation between populations $\left(G_{\mathrm{ST}}=\left(H_{t}\right.\right.$ $\left.\left.H_{s}\right) / H_{t}\right)$, gene flow $\left[N_{\mathrm{m}}=0.25\left(1-G_{\mathrm{ST}}\right) / G_{\mathrm{ST}}\right]$, genetic identity $(I)$ and genetic distance $(D)$ (Yeh et al., 1999). Nei's genetic similarity values, coefficient of genetic differentiation, $N_{\mathrm{m}}, I$ and $D$ were determined for all pairwise combinations of populations (Nei, 1972; Slatkin and Barton, 1989). Jaccard's similarity coefficients were calculated via the NTSYS-pc version 2.1 to generate a dendrogram using the unweighted pair-group method with arithmetic averages (UPGMA) (Rohlf, 2000).

Analysis of molecular variance (AMOVA) was also applied to partition the components of variance within and between P. capsici populations (Excoffier et al., 1992). Input data files for the AMOVA 1.55 programs were generated using DCFA 1.1 (Zhang and Ge, 2002), and the number of permutations was determined at 1000 for significance analysis. AMOVA components were used as estimates of the genetic diversity within and between populations. 


\section{RESULTS}

\section{Primer screening and polymorphism of ISSR-PCR-amplified products}

Based on the preliminary experiments, 13 of the 40 ISSR primers producing clear and reproducible fragments were selected for further analysis. An example of the banding profiles of DNA of isolates using primer UBC835 is shown in Figure 2. For each primer (Table 2), the annealing temperature ranged from $48^{\circ}$ to $54^{\circ} \mathrm{C}$. The minimum and maximum number of bands generated per primer were 8 (UBC809) and 18 (UBC835 and UBC841), respectively, with an average of 12.2 bands per primer. The percentage of polymorphism varied from 50 (UBC809) to $100 \%$ (UBC821, UBC841 and UBC873), with an average of $88.5 \%$ polymorphism across all individuals. A high level of genetic variation was observed. $h$ values ranged from 0.109 to 0.350 , and $I_{s}$ ranged from 0.179 to 0.514 (Table 2), indicating that these 13 primers were appropriate for distinguishing diverse isolates of $P$. capsici. The genetic diversity of different populations was compared as shown in Table 3. Of the 51 isolates, a total of 158 ISSR bands were obtained, of which $142(89.9 \%)$ were polymorphic. Among the three populations, $N_{\mathrm{A}}$ ranged from 1.77 to 1.81 , with an average of 1.90; $N_{\mathrm{E}}$ varied from 1.37 to 1.41 , with a mean of $1.36 ; h$ varied from 0.22 to 0.24 , with an average of 0.21 , and similarly, $I_{s}$ was 0.34 to 0.37 , with a mean of 0.33 . Within populations, among individuals of Pop 1 (between south of the Huai River and north of the Yangtze River), 13 ISSR primers generated a total of 125 bands, of which 97 (77.6\%) were polymorphic; among individuals of Pop 2 (south of the Yangtze River), 13 ISSR primers generated a total of 140 bands, of which $113(80.7 \%)$ were polymorphic, and similarly, among individuals of Pop 3 (north of the Huai River), 13 ISSR primers generated a total of 118 bands, of which 91 (77.1\%) were polymorphic. The results showed that polymorphism existed between different isolates of Anhui Province.
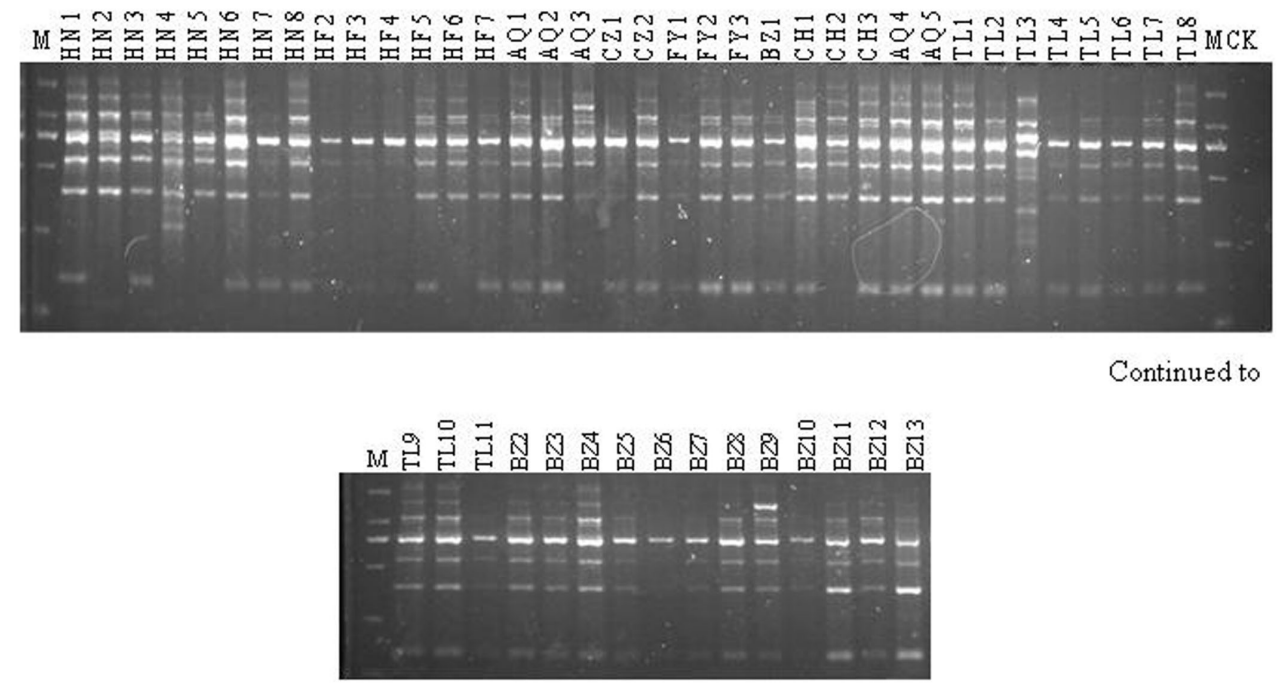

Figure 2. Genetic fingerprints of 51 Phytophthora capsici isolates with primer UBC835. Lane M = DL 2000 marker; $\mathrm{CK}=$ no DNA template. 
Table 2. Properties of ISSR primers used for amplification of Phytophthora capsici isolates in a study of genetic diversity in Anhui China.

\begin{tabular}{|c|c|c|c|c|c|c|c|}
\hline Primer & Sequence $\left(5^{\prime}-3^{\prime}\right)$ & Annealing temperature $\left({ }^{\circ} \mathrm{C}\right)$ & Bands amplified & Polymorphic bands & PPB (\%) & Mean $h$ & Mean $I_{s}$ \\
\hline ILE120 & $\mathrm{CAC}(\mathrm{GA})_{7}$ & 54 & 12 & 11 & 91.7 & 0.179 & 0.294 \\
\hline P10 & $(\mathrm{GA})_{8} \mathrm{TG}$ & 51 & 13 & 12 & 92.3 & 0.176 & 0.286 \\
\hline UBC807 & $(\mathrm{AG})_{8} \mathrm{~T}$ & 52 & 13 & 11 & 84.6 & 0.200 & 0.318 \\
\hline UBC 808 & $(\mathrm{AG})_{8}^{8} \mathrm{C}$ & 54 & 11 & 9 & 81.8 & 0.188 & 0.288 \\
\hline UBC809 & $(\mathrm{AG})_{8}^{8} \mathrm{G}$ & 50 & 8 & 4 & 50.0 & 0.117 & 0.179 \\
\hline UBC811 & $(\mathrm{GA})_{8}^{8} \mathrm{C}$ & 50 & 11 & 9 & 81.8 & 0.216 & 0.339 \\
\hline UBC816 & $(\mathrm{CA})_{8}^{8} \mathrm{~T}$ & 52 & 14 & 13 & 92.9 & 0.245 & 0.379 \\
\hline UBC 821 & $(\mathrm{GT})_{8}^{8} \mathrm{~T}$ & 48 & 9 & 9 & 100.0 & 0.194 & 0.300 \\
\hline UBC835 & $(\mathrm{AG})_{8} \mathrm{YC}$ & 50 & 18 & 17 & 94.4 & 0.218 & 0.331 \\
\hline UBC841 & $(\mathrm{GA})_{8}^{8} \mathrm{YC}$ & 54 & 18 & 18 & 100.0 & 0.292 & 0.438 \\
\hline UBC873 & $(\mathrm{GACA})_{4}$ & 54 & 10 & 10 & 100.0 & 0.350 & 0.514 \\
\hline P15 & $\mathrm{G}(\mathrm{ACAG})_{3} \mathrm{ACAC}_{4}$ & 54 & 12 & 11 & 91.7 & 0.208 & 0.313 \\
\hline P6 & $(\mathrm{AG})_{8} \mathrm{~S}$ & 54 & 9 & 8 & 88.9 & 0.109 & 0.183 \\
\hline
\end{tabular}

$\mathrm{S}=(\mathrm{GC}), \mathrm{Y}=(\mathrm{CT}) . \mathrm{PPB}=$ percentage of polymorphic bands; $h=$ Nei's (1973) gene diversity; $I_{s}=$ Shannon's information index, as a measure of gene diversity.

Table 3. Genetic variations and polymorphic features among isolates of Phytophthora capsici from Anhui,
China, by ISSR markers.
\begin{tabular}{lccccccc}
\hline Population & Total bands & Polymorphic bands & PPB (\%) & Mean $N_{\mathrm{A}}$ & Mean $N_{\mathrm{E}}$ & Mean $h$ & Mean $I_{s}$ \\
\hline Pop 1 & 125 & 97 & 77.6 & 1.78 & 1.40 & 0.23 & 0.35 \\
Pop 2 & 140 & 113 & 80.7 & 1.81 & 1.37 & 0.22 & 0.34 \\
Pop 3 & 118 & 91 & 77.1 & 1.77 & 1.41 & 0.24 & 0.37 \\
Summary & 158 & 142 & 89.9 & 1.90 & 1.36 & 0.21 & 0.33 \\
\hline
\end{tabular}

$\mathrm{PPB}=$ percentage of polymorphic bands; $N_{\mathrm{A}}=$ observed number of alleles, counts the number of alleles with nonzero frequency; $N_{\mathrm{E}}=$ effective number of alleles, estimates the reciprocal of homozygosity; $h=$ Nei's (1973) gene diversity; $I_{s}=$ Shannon's information index, as a measure of gene diversity.

Based on POPGENE analysis, $H_{t}$ of the 51 isolates was 0.2056 and $H_{s}$ was 0.1868 (90.9\%). AMOVA yielded significant genetic differences $(\mathrm{P}<0.001)$ within populations. The results of AMOVA detected $13.6 \%$ of total variation attributable to population divergence between the populations and $86.4 \%$ to individual differences within populations.

\section{ISSR cluster analysis}

Based on the data above, the cluster analysis was performed and the ISSR dendrogram was generated by UPGMA. The results showed that the genetic background of each isolate was not absolutely identical and the similarity coefficient ranged from 0.56 to 0.94 , with an average of 0.84 . All the isolates tested could be divided into 7 clusters at $82 \%$ similarity (Figure 3). Meanwhile, Pop 1 was distributed into 5 clusters (A, B, C, E, and F), mostly cluster A with a percentage of $72.7 \%$; Pop 2 was classified into 4 clusters (A, C, D, and G), mainly cluster D with a percentage of $61.5 \%$; Pop 3 was divided into 4 clusters (A, B, C, and D), mainly cluster $\mathrm{D}$ with a percentage of $68.8 \%$. Isolate $\mathrm{AQ}_{3}$ from Pop 1 was distant from other isolates of Pop 1, and also the isolate designated $\mathrm{TL}_{3}$ from Pop 2 was quite distance from the other isolates of Pop 2 on the dendrogram. The results indicated that Pop 1 comprised more genotypes than the other populations. Generally speaking, most of the isolates from the same 
region grouped together, but not all the isolates from the same region were divided into the same cluster, and isolates from the same location showed no clustering based on the year of sampling in this study.

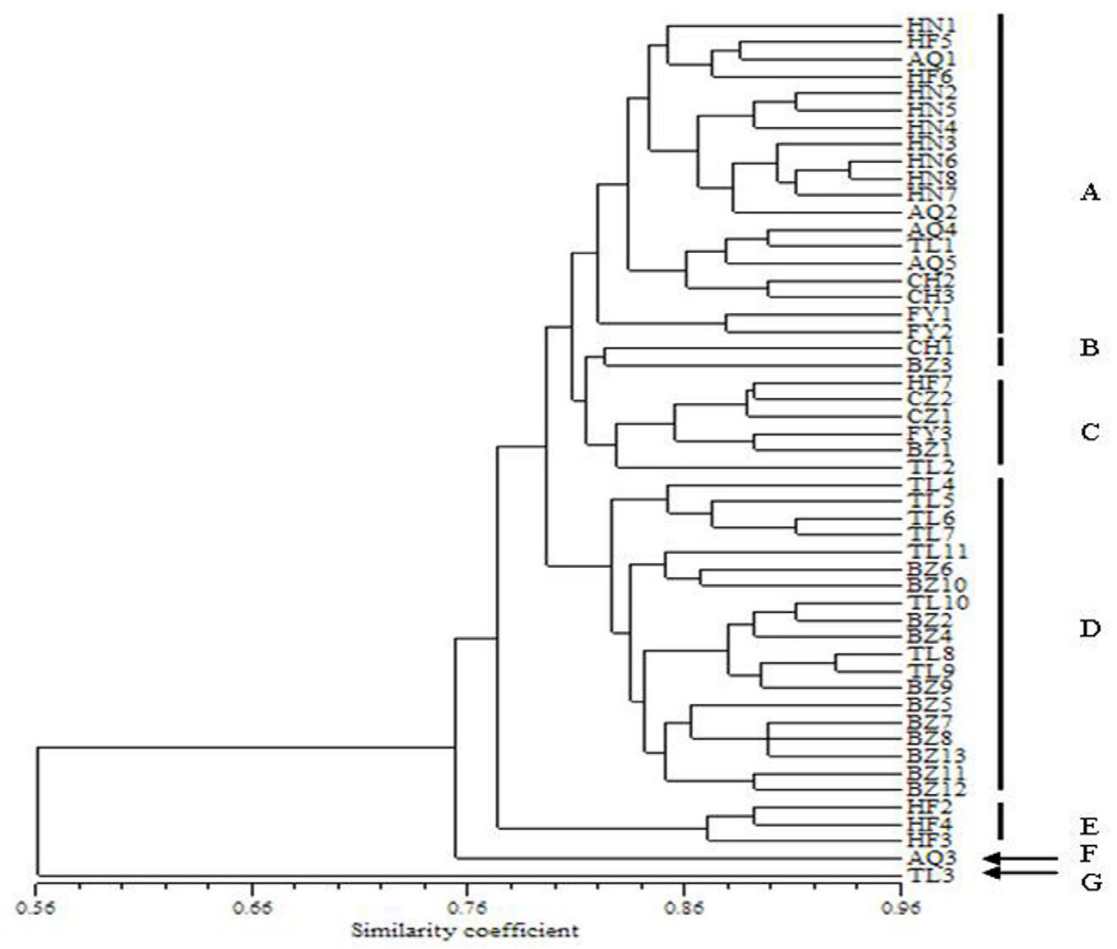

Figure 3. UPGMA dendrogram of genetic relationships of 51 isolates of Phytophthora capsici based on genetic similarity using ISSR marker.

Of the 51 isolates in three populations, 3 of 6 from site D clustered into genotype E, 1 of 5 from site $\mathrm{G}$ clustered into genotype $\mathrm{F}$, and 1 of 11 from site $\mathrm{F}$ clustered into genotype G. Moreover, all 8 isolates from site C of Pop 1, 2 of 6 from site D of Pop 1, 2 of 3 from site E of Pop 1, 4 of 5 from site G of Pop 1, 1 of 11 from site F of Pop 2 and 2 of 3 from site B of Pop 3 clustered into genotype $A ; 1$ of 3 from site $E$ and 1 of 13 from site A clustered into genotype B; 1 of 6 from site D, 2 of all 2 from site H, 1 of 11 from site F, 1 of 3 from site B and 1 of 13 from site A clustered into genotype $\mathrm{C} ; 8$ of 11 from site $\mathrm{F}$ and 11 of 13 from site A clustered into genotype $\mathrm{D}$. Therefore, genotypes $\mathrm{E}, \mathrm{F}$ and $\mathrm{G}$, each originating from one population, were monophyletic while genotypes $\mathrm{A}$ and $\mathrm{C}$, from all three populations, and $\mathrm{B}$, from two populations, were polyphyletic.

\section{Gene flow and genetic differentiation between populations and 8 site locations}

The values of $G_{\mathrm{ST}}$ and $N_{\mathrm{m}}$ between populations (Table 4 ) and 8 site locations were calculated using POPGENE version 1.3.1. The average coefficient of genetic differentiation was 
0.091, indicating moderate genetic differentiation between populations according to Wright's qualitative guideline (Wright, 1978) that $F_{\mathrm{ST}}$ (or $G_{\mathrm{ST}}$ in the this case) values above 0.05 indicate moderate genetic heterogeneity.

Table 4. Gene flow $\left(N_{\mathrm{m}}\right)$ and genetic differentiation coefficient $\left(G_{\mathrm{ST}}\right)$ among populations of Phytophthora capsici.

\begin{tabular}{lccc}
\hline Population & Pop 1 & Pop 2 & Pop 3 \\
\hline Pop 1 & - & 2.894 & 2.804 \\
Pop 2 & 0.080 & - & 4.937 \\
Pop 3 & 0.082 & 0.048 & - \\
\hline
\end{tabular}

Above diagonal was gene flow $\left(N_{\mathrm{m}}\right)$, below diagonal was genetic differentiation coefficient $\left(G_{\mathrm{ST}}\right)$.

The low level of $G_{\mathrm{ST}}$ was caused by a high $N_{\mathrm{m}}$ above the genetic differentiation threshold of 1 according to Wright (1978). $N_{\mathrm{m}}$ was calculated based on the $G_{\mathrm{ST}}$ value $\left(N_{\mathrm{m}}=0.25\right.$ $\left.\left(1-G_{\mathrm{ST}}\right) / G_{\mathrm{ST}}\right)$ and was found to range from 2.804 to 4.937 , with an average of 3.545 , which was higher than the threshold value of $G_{\mathrm{ST}} \cdot N_{\mathrm{m}}$ among populations led to the differences in $G_{\mathrm{ST}}$. For instance, the minimum value of $N_{\mathrm{m}}$ was between Pop 1 and Pop 3, while the $G_{\mathrm{ST}}$ value was maximum, and the genetic exchange between Pop 1 and Pop 3 was relatively less; on the contrary, the maximum value of $N_{\mathrm{m}}$ was between Pop 2 and Pop 3, while the $G_{\mathrm{ST}}$ value was the lowest, indicating that the genetic exchange between these two populations was the most active, resulting in a tendency for convergence.

The maximum and minimum genetic differentiation occurred between a shorter (site E and site H; $215 \mathrm{~km}$ ) and a longer (site A and site F; $479 \mathrm{~km}$ ) geographical distance, respectively, thus demonstrating the negative correlation between these two factors in the genetic differentiation identified in $P$. capsici isolates.

\section{Genetic identity and genetic distance between populations of $P$. capsici}

Matrices of genetic distances and genetic identities (Nei's original measures) between the three populations were established and calculated with POPGENE version 1.3.1. Genetic identity $(I)$ and genetic distance $(D)$ values were obtained from pairwise comparisons (Table 5). The results showed that the highest genetic identity was observed between Pop 2 and Pop 3 (0.9765), followed by that between Pop 1 and Pop 3 (0.9604). In contrast, the smallest genetic distance was observed between Pop 2 and Pop 3 (0.0238), followed by Pop 1 and Pop 3 (0.0404). This phenomenon could be explained by the $N_{\mathrm{m}}$ value, and it was in accordance with the results of ISSR cluster analysis.

Table 5. Genetic identity and genetic distance among populations of Phytophthora capsici isolated in Anhui.
\begin{tabular}{lccc}
\hline Population & Pop 1 & Pop 2 & Pop 3 \\
\hline Pop 1 & - & 0.9596 & 0.9604 \\
Pop 2 & 0.0413 & - & 0.9765 \\
Pop 3 & 0.0404 & 0.0238 & - \\
\hline
\end{tabular}

Above diagonal was genetic identity, below diagonal was genetic distance. 


\section{DISCUSSION}

Pepper Phytophthora blight, caused by P. capsici, was first reported in Jiangsu Province, China in 1940, and then, this disease occurred in both the north and south of China, especially heavily in the Yangtze River Basin, Qinghai, Shanxi, Gansu, Yunnan, and Guangdong; it has been one of the most limiting factors to pepper production (Zhang et al., 2006). Genetic structure of plant pathogen populations is needed to implement effective control strategies (McDonald and Linde, 2002). Although more has been learned about the genetic structure of P. capsici, so far, little is known about that in Anhui Province.

Many studies have shown that molecular markers could detect genetic variation within populations to a certain extent, including pathogenicity variation, geographical differences and host differences (Goodwin and Annis, 1991; Grajal-Martin et al., 1993; Manulis et al., 1994; Nyasse et al., 1999). In the present study, considerable genetic diversity of $P$. capsici was observed with ISSR markers, based on 51 isolates collected from Anhui Province. The differences in genetic diversity in populations were not obvious, largely due to genetic variation within populations. This was in accordance with the ISSR cluster analysis that not all isolates from the same population clustered into one genotype.

Lamour and Hausbeck (2001) used AFLP marker to investigate the spatiotemporal genetic structure of $P$. capsici in Michigan. They found that population differentiation increased with distance, indicating that the genetic distances between populations correlated positively with geographical distances and that geographical separation posed an obstacle to the possibility and frequency of genetic exchanges between populations. The ISSR analysis of the present study revealed that some isolates from site $\mathrm{F}$ (Tongling) were closely related to those from site A (Bozhou), which leads to the controversial conclusion that genetic distances and genetic differentiation are negatively associated with geographic distances. The genetic homogenization between the two locations implied a high level of $N_{\mathrm{m}}$ with each other. Some research has shown that $N_{\mathrm{m}}$ plays a vital role in genetic differentiation and diversity of species and also has a positive effect on the formation and adaptive evolution of species (Garant et al., 2007). The value of $N_{\mathrm{m}}$ between site $\mathrm{F}$ and site A was up to 3.396, showing that genetic exchange was tremendously frequent between these two locations. As previously studied, both A1 and A2 mating types were detected in Anhui (Qi et al., 2012). Gene exchange was probably caused by migration of the oomycete along with plant seeds and/or by transmission of the oospores, which was suitable for explaining the close relationship between isolates separated by a vast geographic distance, since such far dispersal of sporangia seemed unlikely.

AMOVA indicated that genetic variation between $P$. capsici populations was about $13.6 \%$, and it was much higher within populations, accounting for $86.4 \%$. Variation in a population may be a product of mutation. Clonal reproduction in many Phytophthora species, which led to mutation, is the primary source of new genetic variation. Samen et al. (2003) suggested that there was a considerable level of inherent genetic variability among asexual progeny from the same parental isolate of $P$. infestans with RAPD and AFLP markers. Hao et al. (2003) demonstrated that variation in virulence in $P$. sojae asexual reproduction was frequently present and that the variation could not be inherited steadily after successive reproduction. Mutation in most cases could cause no observable changes in phenotypes, but it is not impossible that a portion of the genetic variation observed with these molecular markers could be due to mutations. Another potential explanation for genetic variation is hybridization be- 
tween individuals of different species. P. capsici is a heterothallic species and previous studies found both mating types present in the same location. There has been evidence that back and sibling crosses are possible in $P$. capsici, which accounts for the large reservoirs of naturally occurring genetic variation in oomycete pathogens (Hurtado-Gonzales and Lamour, 2009). Furthermore, some researchers found that Phytophthora could not only carry out intraspecific hybridization but also introgress by interspecific hybridization. Interspecific hybrids between P. cinnamomi and $P$. parasitica have been produced in the laboratory (Boccas and Zentmyer, 1976). Also, progeny obtained from an intercross between P. capsici and P. palmivora and colony morphology, mating type, protein, and pathogenicity to pepper have been tested. This study showed the phenotype and pathogenicity of some progeny differing from either parent.

The study on the genetic diversity of $P$. capsici in Anhui produced important suggestive information for the management of the disease. The presence of high genotypic diversity, along with large population sizes, suggests that the pathogen has a large evolutionary potential that will enable it to adapt and overcome management strategies over time. The fact that $P$. capsici isolates in Anhui have high genotypic diversity is an important aspect for resistance breeding programs, since multiple isolates collected from several regions would have to be included in resistance screenings.

\section{ACKNOWLEDGMENTS}

Research supported by the Commonwealth Specialized Research Fund of China Agriculture (Grant \#3-20) and the Anhui Natural Science Foundation (Grant \#070411028). We thank Rende Qi and Tao Wang for their help with the collection of the Phytophthora capsici isolates, and Yongxia Qi, Fenggang Luan, Tao Jiang, and Qun Wu for assistance with ISSR analysis.

\section{REFERENCES}

Babadoost M and Islam SZ (2001). Seed-treatment for control of seedling death of pumpkins caused by Phytophthora capsici. Phytopathology 91: S4.

Blair MW, Panaud O and McCouch SR (1999). Inter-simple sequence repeat (ISSR) amplification for analysis of microsatellite motif frequency and fingerprinting in rice (Oryza sativa L.). Theor. Appl. Genet. 98: 780-792.

Boccas B and Zentmyer GA (1976). Genetical studies with interspecific crosses between Phytophthora cinnamomi and Phytophthora parasitica. Phytopathology 66: 477-484.

Excoffier L, Smouse PE and Quattro JM (1992). Analysis of molecular variance inferred from metric distances among DNA haplotypes: application to human mitochondrial DNA restriction data. Genetics 131: 479-491.

Förster H, Oudemans P and Coffey MD (1989). Mitochondrial and nuclear DNA diversity within six species of Phytophthora. Exp. Mycol. 14: 18-31.

Garant D, Forde SE and Hendry AP (2007). The multifarious effects of dispersal and gene flow on contemporary adaptation. Funct. Ecol. 21: 434-443.

Gilbert JE, Lewis RV, Wilkinson MJ and Caligari PDS (1999). Developing an appropriate strategy to assess genetic variability in plant germplasm collections. Theor. Appl. Genet. 98: 1125-1131.

Goodwin PH and Annis SL (1991). Rapid identification of genetic variation and pathotype of Leptosphaeria maculans by random amplified polymorphic DNA assay. Appl. Environ. Microbiol. 57: 2482-2486.

Grajal-Martin MJ, Simon CJ and Muehlbauer FL (1993). Use of random amplified polymorphic DNA (RAPD) to characterize race 2 Fusarium oxysporum f. sp. pisi. Phytopathology 83: 612-614.

Hao ZN, Wen JZ and Li YG (2003). Inheritance and variation in virulence of single-zoospore of Phytophthora sojae. Acta Phytopathol. Sin. 33: 347-352.

Hausbeck MK and Lamour KH (2004). Phytophthora capsici on vegetable crops: research progress and management challenges. Plant Dis. 88: 1292-1303. 
Ho HH and Lu JY (1997). A synopsis of the occurrence and pathogenicity of Phytophthora species in mainland China. Mycopathologia 138: 143-161.

Hurtado-Gonzales OP and Lamour KH (2009). Evidence for inbreeding and apomixis in close crosses of Phytophthora capsici. Plant Pathol. 58: 715-722.

Hwang BK and Kim CH (1995). Phytophthora blight of pepper and its control in Korea. Plant Dis. 79: 221-227.

Lamour KH and Hausbeck MK (2001). Investigating the spatiotemporal genetic structure of Phytophthora capsici in Michigan. Phytopathology 91: 973-980.

Latin RX and Rane K (1999). Identification and Management of Pumpkin Diseases. Purdue University, Lafayette.

Leonian LH (1922). Stem and fruit blight of pepper cause by Phytophthora capsici sp. nov. Phytopathology 12: 401-408.

Linde C, Drenth A and Wingfield MJ (1999). Gene and genotypic diversity of Phytophthora cinnamomi in South Africa and Australia revealed by DNA polymorphisms. Eur. J. Plant Pathol. 105: 667-680.

Manulis S, Kogan N and Reuven M (1994). Use of the RAPD technique for identification of Fusarium oxysporum f. sp. dianthi from carnation. Phytopathology 84: 98-101.

McDonald BA (1997). The population genetics of fungi: tools and techniques. Phytopathology 87: 448-453.

McDonald BA and Linde C (2002). The population genetics of plant pathogens and breeding strategies for durable resistance. Euphytica 124: 163-180.

Mchau GRA and Coffey MD (1995). Evidence for the existence of two subpopulations in Phytophthora capsici and a redescription of the species. Mycol. Res. 99: 89-102.

Nei M (1972). Genetic distance between populations. Am. Nat. 106: 283-292.

Nyasse S, Grivet L, Risterucci AM, Blaha G, et al. (1999). Diversity of Phytophthora megakarya in Central and West Africa revealed by isozyme and RAPD makers. Mycol. Res. 103: 1225-1234.

Ochwo MKN, Kamoun S, Adipala E, Rubaihayo PR, et al. (2002). Genetic diversity of Phytophthora infestans (Mont.) de Bary in the eastern and western highlands of Uganda. J. Phytopathol. 150: 541-542.

Oudemans P and Coffey MD (1991). Isozyme comparison within and among worldwide sources of three morphologically distinct species of Phytophthora. Mycol. Res. 95: 19-30.

Qi RD, Wang T, Li P, Ding JC, et al. (2012). Distribution of mating types of Phytophthora capsici and inheritance in asexual progenies in Anhui Province. Acta Phytopathol. Sin. 42: 45-50.

Ristaino JB and Johnston SB (1999). Ecologically based approaches to management of Phytophthora blight on bell pepper. Plant Dis. 83: 1080-1089.

Rohlf FJ (2000). NTSYSpc: Numerical Taxonomy and Multivariate Analysis System. Version 2.1. Exeter Software, Setauket, New York.

Samen FMA, Secor GA and Gudmestad NC (2003). Genetic variation among asexual progeny of Phytophthora infestans detected with RAPD and AFLP markers. Plant Pathol. 52: 314-325.

Silvar C, Merino F and Díaz J (2006). Diversity of Phytophthora capsici in northwest Spain: analysis of virulence, metalaxyl response, and molecular characterization. Plant Dis. 90: 1135-1142.

Slatkin M and Barton NH (1989). A comparison of three indirect methods for estimating the average level of gene flow. Evolution 43: 1349-1368.

Wang JY and Zheng XB (2003). Phylogenetic relationship among isolates of Phytophthora boehmeriae Sawada revealed by RAPD. Mycosystema 22: 228-234.

Wang ZY, Langston DB, Csinos AS, Gitaitis RD, et al. (2009). Development of an improved isolation approach and simple sequence repeat markers to characterize Phytophthora capsici populations in irrigation ponds in southern Georgia. Appl. Environ. Microbiol. 75: 5467-5473.

Wright S (1978). Evolution and the Genetics of Populations. University of Chicago Press, Chicago.

Yang ZH, Zhu JH and Zhang FG (2008). Genetic diversity of Chinese isolates of Phytophthora infestans revealed by AFLP analysis. Mycosystema 27: 351-359.

Yeh FC, Yang RC and Boyle T (1999). POPGENE Version 1.3.1, Microsoft Window-Based Freeware for Population Genetic Analysis. University of Alberta and Centre for International Forestry Research, Alberta.

Zhang FM and Ge S (2002). Data analysis in population genetics. I. analysis of RAPD data with AMOVA. Biodiversity Sci. 10: 438-444.

Zhang J, Wu D, Wang C, Qu H, et al. (2007). Genetic diversity analysis of Quercus mongolica population with InterSimple Sequence Repeats (ISSR) technique. Biodiversity Sci. 15: 292-299.

Zhang ZG, Li YQ, Fan H, Wang YC, et al. (2006). Molecular detection of Phytophthora capsici in infected plant tissues, soil and water. Plant Pathol. 55: 770-775. 